\title{
Implementation of Management for Work-Family Conflict, Family- Work Conflict, and Job Stress that Affect Employee Satisfaction of PT Langgang Buana Perkasa
}

\author{
Nurlaila \\ Department of Management, Faculty of Economics and Business, \\ Universitas Khairun, 97719, Ternate, North Maluku Province, Indonesia \\ Corresponding Author: lela_fekon@yahoo.com
}

\begin{abstract}
ARTICLE INFO
Publication Info:

Research Article

How to cite:

Nurlaila, N. (2020).

Implementation of Management for Work-Family Conflict, FamilyWork Conflict, and Job Stress that Affect Employee Satisfaction of PT Langgang Buana Perkasa. Society, $8(2), 458-469$.
\end{abstract}

DOI: 10.33019/society.v8i2.236

Copyright (C) 2020. Owned by Author(s), published by Society

\section{OPEN ACCESS cC) (-) (-)}

This is an open-access article.

\section{License: Attribution- \\ NonCommercial-ShareAlike (CC BY-NC-SA)}

Received: September 26, 2020;

Accepted: October 16, 2020;

Published: October 31, 2020;

\section{ABSTRACT}

This research aims to analyze the management of work-family conflict, family-work conflict, job stress, and its implementation that affect employee satisfaction of PT Langgang Buana Perkasa. Work and family are two important spheres in an adult's social life. The need will not be met if unemployed. Today, a profession is also a mirror of selfactualization. Without family, individuals will feel alone and there is no place to give love. PT Langgang Buana Perkasa is a company engaged in ground handling services and transportation services on several airlines, which is located at Sultan Babullah airport, Ternate, North Maluku Province, Indonesia. This research used a qualitative descriptive method. Data were obtained through in-depth interviews and questionnaires. Literature and documentation studies are carried out to collect secondary data related to the object of research, including employees of PT Langgang Buana Perkasa, flight schedules, and PT Langgang Buana Perkasa. The data sources were selected using a purposive sampling technique. The results showed that (1) There are three characteristics of work-family conflict. Based on these three characteristics, it indicates that most employees experience conflict in workfamily, but it does not affect job satisfaction; (2) There are five characteristics of family-work conflicts but employees still apply professionalism. This indicates that there is no direct conflict but it can trigger stress due to family demands on religious holidays and public holidays; (3) Physical exhaustion can lead to conflict when faced with family demands regarding that role.

Copyright $($ 2020. Owned by Author(s), published by Society. This is an open-access article under the CC-BY-NC-SA license. 
Implementation of Management for Work-Family Conflict, Family-Work Conflict, and Job Stress that Affect Employee Satisfaction of PT Langgang Buana Perkasa

$\begin{array}{ll}\text { Keywords: } & \text { Employee; Family-Work Conflict; Job } \\ & \text { Satisfaction; Job Stress; Work-Family Conflict }\end{array}$

\section{Introduction}

Every employee of the company certainly wants the maximum level of job satisfaction in each task execution. However, employees also face factors that are considered to hinder job satisfaction. Job satisfaction can improve employee performance and morale, and high job satisfaction can motivate and increase employee productivity (Erbasi \& Arat, 2012, p. 2). One factor that can decrease job satisfaction is family-work conflict. Greenhaus \& Beutell (1985) as cited in Zhang et al, (2012, p. 696) stated that work and family represent two important spheres in an adult's social life. These needs will not be met if unemployed. Today, the work is also a mirror of self-actualization. Without family, individuals will feel alone and there is no place to give love. Work and family are equally important, so each needs a lot of attention. Such attention can be time, energy, and thoughts devoted to both work and family (Carr et al., 2008, p. 249 as cited in Zhang et al., 2012).

According to Greenhaus \& Beutell (1985, p. 77) as cited in Zhang et al, (2012, p. 696), dual role conflict is a form of conflict between roles caused by demands for roles in the workplace and family conflict in several aspects. For example, when an employee is required to work overtime on weekends, that employee cannot spend time on vacation with family. Another example is a dispute in domestic life that results in the employee not concentrating on work.

According to Netemeyer et al, (1996, p. 401) as cited in Zhang et al, (2012, p. 698) there are two types of dual role conflicts, namely work-family conflict (WFC) and family-work conflict (FWC). Work-family conflict occurs when work responsibilities hinder the implementation of family responsibilities. For example, a company requires an employee to work overtime on public holidays, thus making the employee unable to gather with the family and having family vacations. While family-work conflict arises when family activities hinder employee performance. For example, when an employee's child is sick, the employee cannot concentrate on work and if it happens continuously it can decrease job satisfaction. Another example is an employee who did not get permission to work overtime from her husband causing her work to be interrupted. Work-family conflict and family-work conflict are related (bidirectional relationships).

The difficulty of balancing work and family affairs can lead to work-family conflict, where work affairs hinder family life or family affairs hinder employee performance which ultimately affects job satisfaction for both male and female employees. This is in line with the results of research conducted by Husniah (2015, p. 63) and Kurnia \& Endarwati (2016) which stated that work-family conflict has a negative effect on job satisfaction.

A decrease in employee job satisfaction can also occur if the employee experiences stress. The results of research conducted by Dhania (2010, p. 16) showed that job stress is one of the factors that affect job satisfaction. According to Mangkunegara (2011, p. 157), work stress is a feeling of stress experienced by employees in carrying out work.

Stress is a condition in which an individual's condition experience strains because the factors that affect the condition can be obtained from within the individual itself as well as the individual's external environment. Stress has a negative impact on the psychological state of employees (Kurnia \& Endarwati, 2016). Work-Related Stress (WRS) can lead to employee dissatisfaction. The simplest psychological impact of employee stress is to cause employee dissatisfaction which can be manifested in negative behavior at work, increased absenteeism,

Copyright ( $(2020$. Owned by Author(s), published by Society. This is an open-access article under the CC-BY-NC-SA license.

https://doi.org/10.33019/society.v8i2.236

459 
and stopping work (Tarmizi \& Dewi, 2017, p. 316). Furthermore, job satisfaction is strongly affected by job stress on employees. Work-related stress tends to decrease general job satisfaction. Although low to moderate levels of stress may improve performance, employees feel that stress is unpleasant (Nasution, 2016, p. 3). This is in line with the research conducted by Husniah (2015, p. 63), Kurnia \& Endarwati (2016), and Nasution (2016, p. 18) which stated that job stress has a negative effect on job satisfaction.

The need for air transportation services in airports requires human resources capable of providing quality services. In this case, the role of employees is an important thing because it is related to the development of transportation of passengers and goods. The slightest mistake made by employees can have a negative impact on passengers, goods, and also aircraft. Such as flight delays that make passengers late or miss transit flight.

Ground handling service is an activity of an airline related to the handling or service of passengers along with baggage, cargo, and postal equipment, etc. that assisting the movement of aircraft on land while in the airport (departure and arrival). PT Langgang Buana Perkasa is a company engaged in ground handling services and transportation services on several airlines.

To date, PT Langgang Buana Perkasa has 6 business partners consisting of 5 business partners operating in Ternate, North Maluku Province, namely Garuda Indonesia, Sriwijaya Group (Sriwijaya Air and NAM Air), and Lion Group (Lion Air and Batik Air). There is 1 business partner of PT Langgang Buana Perkasa located outside Ternate, North Maluku Province, namely Wings Air. Ground handling services of PT Langgang Buana Perkasa operate exclusively at Sultan Babullah Airport, Ternate, North Maluku Province, Indonesia, with a total employee of 121 people.

There are no operating hours for the company shift system. Employees can rest outside of flight time. Some employees return home and some only stay at their work locations. On weekends and public holidays, airports and airlines still operate, so employees still work. On religious holidays, airports and airlines still operate, on the other hand, employees want to gather with family. Besides, flight schedules often experience delays due to natural factors (volcanic eruption and bad weather) and also because of transit flights. Therefore, employee working hours become flexible with uncertain times. This condition can lead to stress and work-family conflict.

This research aims to analyze the management of work-family conflict, family-work conflict, job stress, and its implementation that affect employee satisfaction of PT Langgang Buana Perkasa.

\section{Literature Review}

\subsection{Job Satisfaction}

Job satisfaction is an important factor in the company, both service and manufacturing companies. The topic of job satisfaction as a scientific concept emerged and attracted attention in the fields of management, social psychology, and operational practice in several periods (Zhu, 2012). Until now the topic is still interesting especially in the field of management.

\subsubsection{Factors Affecting Job Satisfaction}

Factors that affect job satisfaction according to Spector (1985, p. 701) as cited in Novitasari (2015, p. 22), consist of 1) Pay, 2) Promotion, 3) Supervision, 4) Fringe Benefits, 5) Contingent Rewards (performance-based rewards), 6) Operating Procedures (required rules and procedures), 7) Coworkers, 8) Nature of work, and 9) Communication. 
According to Wexley \& Gary (2003, p. 160), as cited in Novitasari (2015, p. 24), job satisfaction is affected by several aspects of work, including wages/salaries, working conditions, supervision, coworkers, work materials, job guarantees, and opportunities for advancement.

\subsubsection{Job Satisfaction Indicators}

Indicators of job satisfaction according to Spector (1985, p. 708) as cited in Novitasari (2015, p. 24) consist of 1) Pay given is appropriate, 2) Contingent rewards when employees make achievements, 3) Supervision support for employees, 4) Work suitability with employees expertise, 5) Vacation opportunities for employees, 6) Good working condition and pleasant coworkers, 7) Fun and not depressed at work. All the indicators above are used in this research.

\subsection{Work-Family Conflict}

Married adult men and women often face conditions where family demands and work are out of balance. According to Bagger \& Li (2012, p. 474), work-family conflict is a conflict that originates from work that hinders family responsibilities. It means that doing a role in the family becomes more difficult because of interference from the role at work. Work-family conflict refers to the situation between responsibilities, and expectations of roles in the family.

\subsubsection{Types of Work-Family Conflict}

Greenhaus \& Beutell (1985) as cited in Zhang et al, (2012, p. 698) identified three types of work-family conflict: time-based, strain-based, and behavior-based. The three types of workfamily conflict described as follows:

1) Time-based conflict. Work-family conflict can affect a person's time. Time spent on activities in one role cannot be used for activities in other roles. In other words, the time needed to carry out one of the demands (family or work) can reduce the time to carry out one of the demands (work or family).

2) Strain-based conflict. Strain-based conflict occurs when pressure from one role (family or work) affects the performance of another role (work or family).

3) Behavior-based conflict. Behavior patterns in certain roles may not be in line with expectations regarding behavior in other roles. Behavior-based conflict is related to discrepancies between behavior patterns and the goals of the roles (work or family).

\subsubsection{Sources of Work-Family Conflict}

Greenhaus \& Beutell (1985, p. 78) stated that there are 3 sources of work-family conflict, consists of:

1) Time. This relates to the number of hours worked per week, the work shift system, inflexible work schedules, the number and frequency of overtime, and irregularities in working hour arrangements.

2) Role strain. This relates to unclear roles at work, role conflicts at work, stress at work, and lack of support from superiors.

3) Behavior. This relates to managers' expectations of employee behavior to be aggressive, objective, and maintain confidentiality in job roles.

\subsubsection{Indicators of Work-Family Conflict}

According to Netemeyer et al, (1996, p. 401), there are 5 indicators of work-family conflict, consists of: 
1) Work demands disturb the family. Work demands such as continuing education abroad disturb the family.

2) Work reduces self-involvement in the family. Work causes a lack of time together with family.

3) Work interferes with the wishes of the family. Due to the work demands, the wishes and hopes of the family cannot be realized.

4) Work hinders activities in the family. Work demands hinder or interfere with important family activities and events.

5) The conflict between work commitments and family responsibilities. Commitment to work and family responsibilities cannot be balanced.

All indicators above are used in this research with each indicator represented by one statement.

\subsection{Family-Work Conflict}

According to Bagger \& Li (2012, p. 474), family-work conflict is a conflict that originates from the family that hinders work responsibilities. For example, an employee is late for work due to household matters such as taking the child to daycare.

\subsubsection{Source of Family-Work Conflict}

Greenhaus \& Beutell $(1985$, p. 78) stated that there are 3 sources of family-work conflict, consists of:

1) Time. This relates to activities in the family such as employees who are married and have children, partner life activities, and extended families.

2) Role strain. This relates to conflicts in the family and the lack of support from the family in carrying out work activities.

3) Behavior. This relates to family expectations in a warm and open relationship.

\subsubsection{Indicators of Family-Work Conflict}

According to Netemeyer et al, (1996, p. 401), there are 5 indicators of family-work conflict, consists of:

1) Family demands hinder employees' work. Family demands interfere with employees in doing work.

2) Family results in an employee's job loss. Family makes employees lose their opportunity to get a job or complete their work.

3) Family hinder the desires of employees at work. Family interferes with employees' desires or achievements in their work.

4) Family hinder the responsibilities in employee's work. Family makes employees unable to carry out their responsibilities at work.

5) Busyness in the family, upset coworkers. Busyness in the family makes coworkers feel disturbed.

\subsection{Job Stress}

According to Rivai \& Sagala (2011, p. 516) argued that work stress is a condition of strain that creates a physical and psychological imbalance that affects emotions, thought processes, and the condition of an employee. Furthermore, work stress is a feeling of stress experienced by employees in dealing with work (Mangkunegara, 2011, p. 157). 
Job stress is a stressful condition that affects a person's thought processes, emotions, and conditions, as a result, excessive stress can threaten a person's ability to deal with the environment and ultimately will hinder the execution of tasks (Handoko, 2001, p. 200).

Job stress arises because of the demands and resources of an employee. The demands referred to are the responsibilities, pressures, obligations, or uncertainties faced by employees whereas resources are things that are controlled by an employee which are used to meet demands. Stress is a condition that occurs when faced with pressure or duties or responsibilities and the inability to handle it continuously for a long period (Mansoor et al., 2011, p. 50).

According to Robbins \& Judge (2007), stress is a dynamic condition of an individual being faced with opportunities, demands, and resources related to that individual's desires and the results are considered uncertain but important.

\section{Research Methodology}

This research used a qualitative descriptive method. Data were obtained through in-depth interviews and questionnaires. Literature and documentation studies are carried out to collect secondary data related to the object of research, including employees of PT Langgang Buana Perkasa, flight schedules, and PT Langgang Buana Perkasa. The data sources were selected using a purposive sampling technique. The sampling was based on the research choice on the aspects and focus in certain situations and continuously throughout the research conducted following the research objectives with certain criteria. The sample in the research was employees of PT Langgang Buana Perkasa, represented by 10 married employees, consisting of 8 employees who are married and have children, and 2 employees who are married but do not have children. The purpose of this sample selection is due to employees experiencing workfamily conflict, family-work conflict, and job stress.

The research was conducted at PT Langgang Buana Perkasa located at Sultan Babullah Airport, Ternate, North Maluku Province, Indonesia. PT Langgang Buana Perkasa has 6 business partners consisting of 5 business partners operating in Ternate, North Maluku Province, namely Garuda Indonesia, Sriwijaya Group (Sriwijaya Air and NAM Air), and Lion Group (Lion Air and Batik Air). There is 1 business partner of PT Langgang Buana Perkasa located outside Ternate, North Maluku Province, namely Wings Air. In operating ground handling services, PT Langgang Buana follows airport operating hours and airline flight schedules. There is no implementation of the shift system by the company to employees.

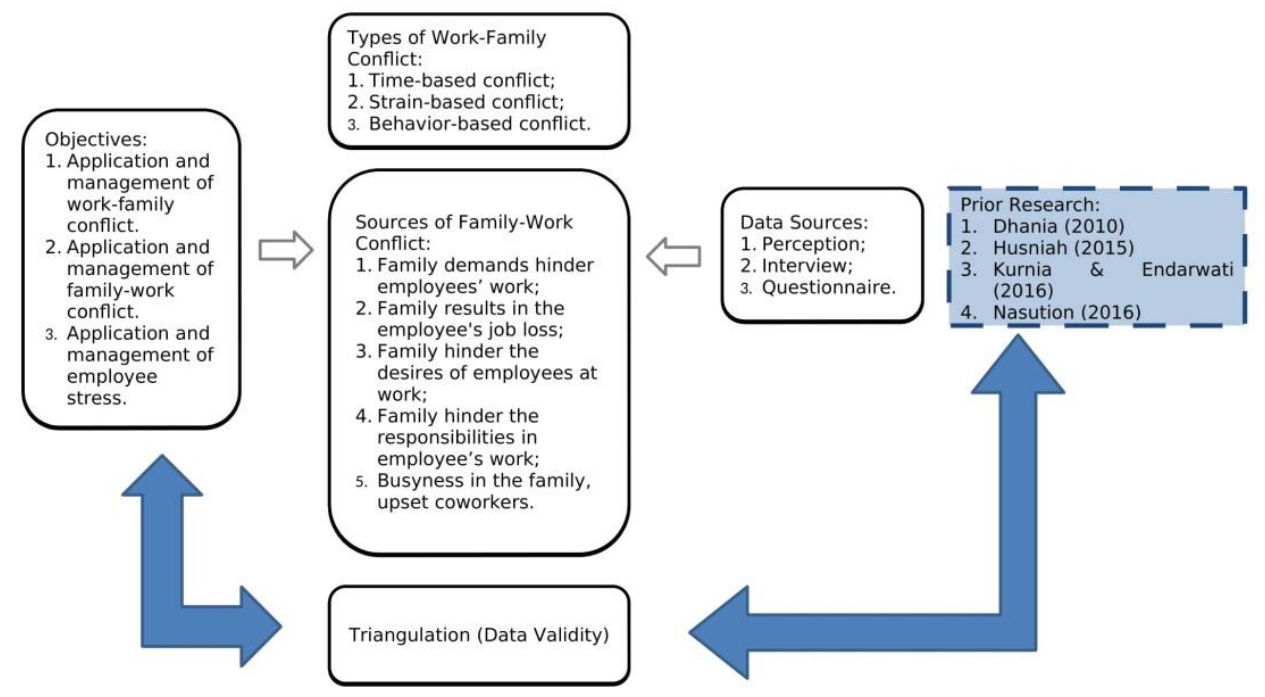

Figure 1. Research Roadmap

Copyright $\odot$ 2020. Owned by Author(s), published by Society. This is an open-access article under the CC-BY-NC-SA license. https://doi.org/10.33019/society.v8i2.236

463 


\section{Results and Discussion}

\subsection{Results}

The characteristics of work-family conflict, family-work conflict, and job stress found in this research are as follows:

Table 1. The Characteristics of Work-Family Conflict

\begin{tabular}{|c|c|c|}
\hline Question & Option & Respondent Answer \\
\hline \multirow{5}{*}{ Time-Based Conflict } & Strongly Agree & 0 \\
\hline & Agree & 3 \\
\hline & Neutral & 0 \\
\hline & Disagree & 4 \\
\hline & Strongly Disagree & 3 \\
\hline \multirow{5}{*}{ Strain Based Conflict } & Strongly Agree & 0 \\
\hline & Agree & 4 \\
\hline & Neutral & 1 \\
\hline & Disagree & 3 \\
\hline & Strongly Disagree & 2 \\
\hline \multirow{5}{*}{ Behavior-Based Conflict } & Strongly Agree & 1 \\
\hline & Agree & 3 \\
\hline & Neutral & 1 \\
\hline & Disagree & 5 \\
\hline & Strongly Disagree & 1 \\
\hline
\end{tabular}

Based on Table 1, time-based conflict, on 10 respondents, related to the time respondents spend on activities in one role cannot be used for other role activities. For example, domestic roles such as cooking, accompanying children in learning, parenting, and family vacations. None of the respondents who answered strongly agree, three respondents answered agree, none responded answered neutral, four respondents answered disagree, and three respondents answered strongly disagree. Most of the respondents answered disagree and strongly disagree with the occurrence of time-based conflict. This indicates that working with family responsibilities is not an issue because respondents can manage the time for both (work and family).

Strain-based conflict is the second type of work-family conflict. This is because the pressure of one of the roles (family or work) will affect employee performance. For example, a family event that requires the employee but on the other hand the presence of the employee is very important in the workplace. None of the respondents who answered strongly agree, four respondents answered agree, one respondent answered neutral, three respondents answered disagree, and two respondents answered strongly disagree. Most of the respondents answered agree with the occurrence of strain-based conflict because they considered their role as a wife or husband or as a mother or father in a family event, and family vacation time was important, while respondents also agreed on their role in carrying out work duties at work. This causes strain between their roles.

Behavior-based conflict is behavior patterns in certain roles that may not be in line with expectations regarding behavior in other roles. Behavior-based conflict is related to discrepancies between behavior patterns and the goals of the roles (work or family), for 
example, how to establish communication and cooperation with family members as well as how to establish communication and cooperation with coworkers. One respondent answered strongly agree, three respondents answered agree, one respondent answered neutral, five respondents answered disagree, and one respondent answered strongly disagree. Most of the respondents answered disagree with the occurrence of behavior-based conflict. This indicates that they can establish effective communication and implement good ways of working together in the family and work environment.

Table 2. The Characteristics of Family-Work Conflict

\begin{tabular}{|c|c|c|}
\hline Question & Option & Respondent Answer \\
\hline \multirow{5}{*}{$\begin{array}{l}\text { Family demands hinder } \\
\text { employees' work }\end{array}$} & Strongly Agree & 0 \\
\hline & Agree & 5 \\
\hline & Neutral & 0 \\
\hline & Disagree & 3 \\
\hline & Strongly Disagree & 2 \\
\hline \multirow{5}{*}{$\begin{array}{l}\text { Family results in the employee's } \\
\text { job loss }\end{array}$} & Strongly Agree & 0 \\
\hline & Agree & 1 \\
\hline & Neutral & 0 \\
\hline & Disagree & 7 \\
\hline & Strongly Disagree & 2 \\
\hline \multirow{5}{*}{$\begin{array}{l}\text { Family hinder the desires of } \\
\text { employees at work }\end{array}$} & Strongly Agree & 1 \\
\hline & Agree & 5 \\
\hline & Neutral & 0 \\
\hline & Disagree & 3 \\
\hline & Strongly Disagree & 1 \\
\hline \multirow{5}{*}{$\begin{array}{l}\text { Family hinder the responsibilities } \\
\text { in employee's work }\end{array}$} & Strongly Agree & 0 \\
\hline & Agree & 4 \\
\hline & Neutral & 1 \\
\hline & Disagree & 2 \\
\hline & Strongly Disagree & 3 \\
\hline \multirow{5}{*}{$\begin{array}{l}\text { Busyness in the family, upset } \\
\text { coworkers }\end{array}$} & Strongly Agree & 0 \\
\hline & Agree & 1 \\
\hline & Neutral & 0 \\
\hline & Disagree & 5 \\
\hline & Strongly Disagree & 4 \\
\hline
\end{tabular}

Based on Table 2, on 10 respondents, related to family demands hinder employees' work, none of the respondents who answered strongly agree, five respondents answered agree, none of the respondents who answered neutral, three respondents answered disagree, and two respondents answered strongly disagree. Most of the respondents agreed that there were demands from the family. It will hinder their work. This causes conflicts or problems due to a lack of focus and attention from employees, increases absenteeism, and even results in employees losing their jobs. This kind of impact makes employees prefer to work rather than family demands. The choice of employees to focus on work has an impact on the rewards given 
by the company and employees avoid the risk of losing their jobs. The result of this choice causes conflict in the family due to a lack of employee attention and time for the family.

Related to the family results in the employee's job loss, none of the respondents who answered strongly agree, one respondent answered agree, none of the respondents who answered neutral, seven respondents answered disagree, and two respondents answered strongly disagree. Most of the respondents answered that they did not agree that family was one of the factors that caused them to lose their job or the opportunity to get a job or complete work tasks. This is because most respondents said that if they lost their job, they would look for another job. Others said that they lost their jobs because they were not lucky. This indicates that the respondent loves family more than work.

Related to family hinder the desires of employees at work, the family hinders the achievement of employees at work, the question to respondents was to prioritize togetherness in the family rather than working actively and working overtime to get a promotion. One respondent answered strongly agree, five respondents answered agree, none of the respondents who answered neutral, three respondents answered disagree, and one respondent answered strongly disagree. This indicates that most respondents are aware that there will be an influence on the desire to achieve a high career at work if supported by their family.

Related to the family hinder the responsibilities in employee's work, the family makes employees unable to carry out their responsibilities at work, and the family interests make employees not working optimally. None of the respondents who answered strongly agree, four respondents answered agree, one respondent answered neutral, two respondents answered disagree, and three respondents answered strongly disagree. This indicates that most of the respondents recognize that the family interests or affairs can affect the responsibilities in their work and can create conflict and cause stress if they are not able to manage it as well as possible.

Related to busyness in the family, upset coworkers, busyness in the family makes coworkers feel disturbed, and employees' full attention to the family disrupted cooperative relations and communication with coworkers. None of the respondents who answered strongly agreed, one respondent answered agree, none of the respondents who answered neutral, five respondents answered disagree, and four respondents answered strongly disagree. This indicates that most respondents do not agree that if an employee focuses on family activities it will affect relationships with coworkers, both organizationally and personally. This is because they understand each other to provide mutual support.

\subsection{Discussion}

Based on respondents' answers, employees can manage time for work and time for family. Before leaving for work, female respondents have prepared food for the family. All household needs of male respondents have been arranged by the respondent's wife. Vacation activities with family are carried out outside the working hours. Respondents admit that their role is needed in the family at certain times and becomes a dilemma because tasks in the workplace must be carried out at the same time. Psychologically, human behavior sometimes arises from the implementation of these two roles. Family demands and work demands can create strain in roles, especially in the family. Female employees experience this dilemma more than male employees. Family demands and work demands affect psychology and cause fatigue and poor physical condition.

From the three characteristics of work-family conflict above, it shows that most of the respondents have a conflict with work-family, but it did not affect job satisfaction. The results of

Copyright ( $(2020$. Owned by Author(s), published by Society. This is an open-access article under the CC-BY-NC-SA license. https://doi.org/10.33019/society.v8i2.236

466 
interviews with the Head of the Human Resource Management of PT Langgang Buana Perkasa stated that employees have been directed from the beginning that employees should instill selfsatisfaction at the workplace because it is important and affects employee performance.

Family-work conflicts are also a difficult condition to deal with. Employees asking for permission not to work are one of the ways they usually do. But there are rules at work that limit employee permissions. This is a dilemma for respondents if there is a demand for their attendance in family activities and their work schedule.

Most of the respondents who are married have a great love for their families. Respondents will ask permission not to work if there is an urgent family matter. Respondents considered that if they lost their job, it was due to factors caused by individuals to the company, not due to family factors because in principle the family still supported their activities. They can manage their time according to existing working conditions.

On the other hand, respondents also had problems, especially on holidays and religious holidays. Employees must continue to work according to the work schedule even though there are no protests from employees. However, employees are worried that they will not be able to spend time with their families on holidays and religious holidays because they have to maintain work professionalism. This indicates that the conflict does not occur directly but triggers employee stress. To reduce this impact, the company still pays attention to the needs of employees to maintain job satisfaction.

Respondents also think that family support for their work activities will affect performance and require understanding from family members. Thinking about the family when the respondent is working is not a problem when faced with having to work to pursue a career and achievement with the demands of the family at home. However, the arrival and departure times of flights that are sometimes not on time make it difficult for them to manage.

Attention and responsibility to the family do not hinder work relationships in the work environment. Each of them carries out their duties according to their duties and responsibilities as employees. Good relations in the work environment affect work activities and make them feel satisfied and comfortable at work.

\section{Conclusion}

From the research results it can be concluded as follows: (1) There are three characteristics of work-family conflict. Based on these three characteristics, it indicates that most employees experience conflict in work-family, but it does not affect job satisfaction; (2) There are five characteristics of family-work conflicts but employees still apply professionalism. This indicates that there is no direct conflict but it can trigger stress due to family demands on religious holidays and public holidays; (3) Physical exhaustion can lead to conflict when faced with family demands regarding that role.

\section{Acknowledgment}

The author is grateful to express gratitude to all of those who have had the pleasure to work during this research conducted.

\section{Declaration of Conflicting Interests}

The authors have declared no potential conflicts of interest concerning the research, authorship, and/or publication of this article. 


\section{References}

Bagger, J., \& Li, A. (2012). Being important matters: The impact of work and family centralities on the family-to-work conflict-satisfaction relationship. Human relations, 65(4), 473-500. https://doi.org/10.1177/0018726711430557

Dhania, D. R. (2010). Pengaruh Stres Kerja, Beban Kerja, terhadap kepuasan Kerja (studi pada medical representatif di Kota Kudus). Jurnal Psikologi: PITUTUR, 1(1), 15-23. Retrieved from https://jurnal.umk.ac.id/index.php/PSI/article/view/21

Erbasi, A., \& Arat, T. (2012). The Effect of Financial and Non-financial Incentives on Job Satisfaction: An Examination of Food Chain Premises in Turkey. International Business Research, 5(10), 136-145. https:// doi.org/10.5539/ibr.v5n10p136

Greenhaus, J. H., \& Beutell, N. J. (1985). Sources of conflict between work and family roles. Academy of management review, 10(1), 76-88. https:// doi.org/10.5465/amr.1985.4277352

Handoko, T. H. (2001). Manajemen Personalia dan Sumber Daya Manusia. Yogyakarta, Indonesia: Penerbit BPFE.

Husniah, A. (2015). Pengaruh Konflik Pekerjaan-Keluarga dan Stres Kerja terhadap Kepuasan Kerja Perawat RS PKU Muhammadiyah Yogyakarta (Thesis). Universitas Muhammadiyah Yogyakarta. Retrieved from https://eprints.uny.ac.id/26427/

Kurnia, D. N., \& Endarwati, M. L. (2016). Pengaruh Work-Family Conflict dan Stres Kerja Terhadap Kepuasan Kerja Karyawan Pada PT. Bank Rakyat Indonesia (Persero) Tbk Cabang Wonosobo. Jurnal Manajemen Bisnis Indonesia (JMBI), 5(2), 132-143. Retrieved from http://journal.student.uny.ac.id/ojs/index.php/jmbi/article/view/5018

Mangkunegara, A. P. (2011). Manajemen Sumber Daya Manusia Perusahaan. Bandung, Indonesia: PT Remaja Rosdakarya.

Mansoor, M., Fida, S., Nasir, S., \& Ahmad, Z. (2011). The impact of job stress on employee job satisfaction a study on telecommunication sector of Pakistan. Journal of Business Studies Quarterly, 2(3), 50-56. Retrieved from http://citeseerx.ist.psu.edu/viewdoc/download?doi=10.1.1.651.8287\&rep=rep1\&type=pd $\mathrm{f}$

Nasution, I. S. (2016). Pengaruh Konflik Peran Ganda (Work Family Conflict \& Family Work Conflict) dan Stres Kerja terhadap Kepuasan Kerja (Studi Pada RS PKU Muhammadiyah Yogyakarta) (Thesis). Universitas Muhammadiyah Yogyakarta. Retrieved from http://repository.umy.ac.id/handle/123456789/5607

Netemeyer, R. G., Boles, J. S., \& McMurrian, R. (1996). Development and validation of workfamily conflict and family-work conflict scales. Journal of Applied Psychology, 81(4), 400410. https:// doi.org/10.1037/0021-9010.81.4.400

Novitasari, A. (2015). Pengaruh Konflik Pekerjaan-Keluarga dan Konflik Keluarga-Pekerjaan pada Kepuasan Kerja dengan Sentralitas Pekerjaan-Keluarga sebagai Variabel Moderator (Studi pada Perawat Instalasi Rawat Inap Jiwa RSJ Prof. Dr. Soerojo Magelang) (Thesis). Universitas Negeri Semarang. Retrieved from http://lib.unnes.ac.id/22082/

Rivai, V., \& Sagala, E. J. (2011). Manajemen Sumber Daya Manusia Untuk Perusahaan (2nd ed.). Jakarta, Indonesia: Rajawali Pers.

Robbins, S. P., \& Judge, T. (2007). Organizational Behavior (12th ed.). Upper Saddle River, NJ, United States: Prentice Hall.

Tarmizi, A., \& Dewi, S. S. (2017). Pengaruh Stress dan Tingkat Kepuasan Kerja terhadap Komitmen Karyawan Studi Kasus PT. FEI. Jurnal Riset Manajemen dan Bisnis (JRMB) Fakultas Ekonomi UNIAT, 2(3), 315-322. https://doi.org/10.36226/jrmb.v2i3.64 
Implementation of Management for Work-Family Conflict, Family-Work Conflict, and Job Stress that Affect Employee Satisfaction of PT Langgang Buana Perkasa

Zhang, M., Griffeth, R. W., \& Fried, D. D. (2012). Work-family conflict and individual consequences. Journal of Managerial Psychology, 27(7), 696-713. https:/ / doi.org/10.1108/02683941211259520

Zhu, Y. (2012). A Review of Job Satisfaction. Asian Social Science, 9(1), 293-298. https:// doi.org/10.5539/ass.v9n1p293

\section{About the Author}

Nurlaila is an Associate Professor at the Department of Management, Faculty of Economics and Business, Universitas Khairun, Indonesia.

E-Mail: lela_fekon@yahoo.com 